\section{ASSET MANAGEMENT, PT TAISHO PHARMACEUTICAL TBK}

\author{
Aldi Wiratama, Nusa Muktiadji dan Nani Cahyani \\ Program Studi Manajemen, Sekolah Tinggi Ilmu Ekonomi Kesatuan \\ Bogor, Indonesia \\ Email : adithyaarianugraha@gmail.com
}

Assets, Assets

Management,

Financial

Performance

145

\section{ABSTRACT}

Assets are important aspects of a company. Many firms still consider physical assets management as a tool or instrument in assets list management. The reality reveals that many cases initially started off from assets mismanagement, and eventually cause great loss to the company. Assets management is a process of wealth management both tangible and intangible ones, that are expected to have economic values and aimed at gaining profit and reduce costs efficiently and effectively. An appropriate assets management improves financial performance and increases revenues from assets utilization and reduces maintenance costs. The study aims at identifying how the financial performance and assets management in PT Taisho Pharmaceutical, Tbk. seen from its financial ratios and how its financial performance compared to industrial average financial performance of pharmaceutical sub sector. The financial reports used in this study are obtained from idx.co.id for the periods of 2012-2016. Analytical methods used are trend analysis, operating cycle, and financial ratio analysis.

Based on the analysis, it can be concluded that assets management of PT Taisho Pharmaceutical generally fall into good category. This can be viewed from the activity ratios (TATO, CATO, FATO, INTO, ARTO) which are visibly increasing. Nonetheless, the company could not afford to optimize the efficiency of cost of goods sold and operating cost, and it has caused a less maximum gain in profits.

The percentage of cost of goods sold and operating costs are larger than the sales percentage. The large amount of cost of goods sold is due to company's policy granting employees extra training to produce more innovation for new products, and the increasing operating costs occurred owing to company's increaseing sales volumes which resulted in additional costs for packing, delivery, and electrical engines. There are still some major improvements to make, considering some of the financial ratios are still under the average industrial score for pharmaceutical sub sector. The improvement of financial performance is necessary to push the profit gains and advancing the stakeholders wellfare.

Keywords: Assets, Assets Management, Financial Performance

\section{PENDAHULUAN}

PT Taisho Pharmaceutical Indonesia Tbk, awalnya didirikan dengan nama PT Squibb Indonesia pada tahun 1970, dan memulai kegiatan komersialnya pada tahun 1972. Perusahaan bergerak di bidang farmasi yaitu pabrikan obat-obatan Over-the-Counter ("OTC") dan Etikal, baik untuk pasar dalam negeri dan luar negeri. Kantor pusat SQBB atau SQBI terletak di Wisma Tamara, Jakarta, sedangkan pabrik berlokasi di JI. Raya
Submitted: JANUARI 2019

Accepted: APRIL 2019

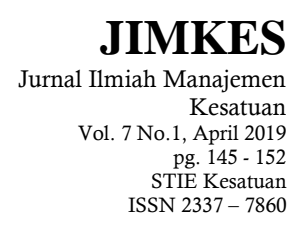


Assets, Assets

Management,

Financial

Performance

146
Bogor Km. 38, Cilangkap Depok. Pemegang saham yang memiliki 5\% atau lebih saham Taisho Pharmaceutical Indonesia Tbk adalah Taisho Pharmaceutical Co.,Ltd. (90,51\% saham biasa) dan Taisho Pharmaceutical Co.,Ltd. (7,46\% saham preferen).

Dalam Anggaran Dasar Perusahaan, ruang lingkup kegiatan SQBB atau SQBI adalah mengembangkan, mendaftarkan, memproses, memproduksi dan menjual produk kimia, farmasi dan kesehatan. Saat ini, kegiatan utama Taisho adalah bergerak di bidang farmasi yaitu pabrikan obat-obatan Over-the-Counter "OTC" (merek Counterpain dan Tempra) dan Etikal (merek Kenacort, Dramamine, Kenalog, Myco-Z ointment, dan Mycostatin). Pada tahun 1983, SQBI memperoleh pernyataan efektif dari Bapepam-LK untuk melakukan Penawaran Umum Perdana Saham SQBI (IPO) kepada masyarakat sebanyak 972.000 dengan nilai nominal Rp1.000,- per saham dengan harga penawaran Rp1.050,- per saham. Saham-saham tersebut dicatatkan pada Bursa Efek Indonesia (BEI) pada tanggal 29 Maret 1983.

Sehubungan dengan hal tersebut di atas, dirasakan perlu untuk melakukan penelitian yang terkait dengan Analisis Manajemen Aset pada PT Taisho Pharmeceutical Indonesia Tbk yang Terdaftar di Bursa Efek Indonesia.

\section{TINJAUAN PUSTAKA}

Menurut Sugiama (2013:15) manajemen aset adalah ilmu dan seni untuk memandu pengelolaan kekayaan yang mencakup proses merencanakan kebutuhan aset, mendapatkan, menginventarisasi, melakukan legal audit, menilai, mengoperasikan, memelihara, membaharukan mengalihkan aset secara efektif dan efisien

Manajemen Aset terdiri dari dua kata yaitu Manajemen dan Aset. Pengertian manajemen adalah proses yang mencakup 4 fungsi dasar, yaitu perencanaan, pengorganisasian, pengarahan, dan pengawasan. Sedangkan yang disebut dengan aset pada umumnya adalah kekayaan. Kekayaan itu bisa dalam bentuk kekayaan berwujud (Fisik) dan juga tidak berwujud. Kekayaan yang berwujud misalnya tanah, gedung, peralatan, mesin, kendaraan dan lain-lain. Sedangkan kekayaan yang tidak berwujud seperti hak cipta, hak paten, hak kekayaan intelektual dan lain-lain. Dalam perspektif lain aset juga diartikan segala sesuatu yang memiliki nilai ekonomi yang dapat dimiliki baik oleh individu, perusahaan, maupun pemerintah yang dapat dinilai secara finansial.

Manajemen aset adalah suatu potensi yang dimiliki oleh organisasi atau pribadi untuk mencapai visi misi dan tujuan bersama maupun tujuan khususnya. Manajemen Aset dapa didefinisikan sebagai suatu manajemen proses secara global untuk membuat dan melaksanakan nilai keputusan tertinggi tentang penggunaan dan perawatan aset secara konsisten.

Menurut Sugiama (2013: 16) tujuan manajemen asset adalah untuk pengambilan keputusan yang tepat agar aset yang dikelola berfungsi secara efektif dan efisien. Tujuan manajemen aset dapat ditentukan dari berbagai dimensi atau sudut pandang. Secara umum tujuan manajemen aset adalah untuk pengambilan keputusan yang tepat agar aset yang dikelola berfungsi secara efektif dan efisien. Efektif adalah pencapaian hasil yang sesuai dengan tujuan sebagaimana yang telah ditetapkan sebelumnya. Efektif dalam pengelolaan aset berarti aset yang dikelola dapat mencapai tujuan yang diharapkan organisasi bersangkutan, misal mencapai kinerja tertinggi dalam pelayanan pelanggan. Sedangkan efektivitas berarti derajat keberhasilan yang dapat dicapai berdasarkan tujuan yang telah ditetapkan 


\section{Rasio Likuiditas}

Assets, Assets

Rasio likuiditas adalah rasio yang mengukur kemampuan perusahaan memenuhi kewajiban jangka pendeknya. Rasio-rasio ini dapat dihitung melalui sumber informasi tentang modal kerja yaitu pos-pos aktiva lancar dan hutang lancar. Dengan demikian rasio likuiditas berpengaruh dengan kinerja keuangan perusahaan sehingga rasio ini memiliki hubungan dengan harga saham perusahaan. Rasio Likuiditas terdiri dari:

- Ratio Lancar $=($ Aset Lancar/Hutang Lancar $)$

- Ratio Cepat $=($ Aset Lancar-Persediaan $) /$ Hutang Lancar

- Ratio Kas = (Aset Lancar/ Hutang Lancar)

\section{Rasio Aktivitas}

Rasio aktivitas adalah rasio yang mengukur seberapa efektif perusahaan dalam memanfaatkan semua sumber daya yang ada padanya. Houston (2011:136) mengatakan bahwa rasio aktivitas merupakan rasio yang digunakan untuk mengukur keefektifan perusahaan menggunakan aktivanya dibandingkan dengan penjualan yang diproyeksikan dalam laporan keuangan. Rasio aktivitas terdiri dari:

- Perputaran Total Aset = $($ Penjualan $/$ Total Aset $)$

- Perputaran Aset Lancar $=($ Penjualan / Aset Lancar $)$

- Perputaran Piutang $=($ Penjualan/ Piutang $)$

- Perputaran Persediaan $=($ Harga Pokok Penjualan $/$ Persediaan $)$

- Perputaran Aset Tetap = (Penjualan / Aset Tetap $)$

- Perputaran Modal Kerja = (Penjualan / (Aset Lancar-Hutang Lancar)

- Perputaran Hutang $=($ Harga Pokok Penjualan $/$ Hutang Usaha $)$

\section{Profitabilitas}

Menurut Subramanyam, K. R., \& Wild, J. J. (2013:109) Profitabilitas merupakan ringkasan hasil bersih aktivitas operasi usaha dalam periode tertentu yang dinyatakan dalam istilah keuangan. Laba merupakan informasi perusahaan paling diminati dalam pasar uang. Pemahaman dua peranan laba ini untuk menentukan dan menjelaskan laba suatu usaha pada satu periode merupakan tujuan utama laporan laba rugi. Peranan laba yang pertama yaitu untuk menyediakan, baik pengukuran perubahan kekayaan pemegang saham selama periode maupun mengestimasi laba usaha sekarang, yaitu sampai sejauh mana perusahaan dapat menutupi biaya operasi dan menghasilkan pengembalian kepada pemegang sahamnya. Peranan yang kedua yakni sebagai indikator profotabilitas perusahaan, karena membantu dalam mengestimasi potensi laba dimasa depan, yang tidak diragukan lagi merupakan satu dari tugas terpenting dalam analisis usaha.

\section{Rasio Profitabilitas}

Rasio profitabilitas merupakan rasio yang menggambarkan kemampuan perusahaan dalam mendapatka laba melalui semua kemampuan dan sumber yang ada seperti kegiatan penjualan, kas, modal, jumlah karyawan, jumlah cabang dan sebagainya (Syafri, 2008:304). Jenis-Jenis Rasio Profitabilitas, yaitu:
Management,

Financial

Performance 
Assets, Assets

Management,

Financial

Performance
- Gross Profit Margin = $($ Penjualan-Harga pokok penjualan $) /$ Penjualan

- Operating Profit Margin = $($ Laba Usaha $) /$ Penjualan

- Net Profit Margin = $($ Laba Bersih Setelah Pajak $) /$ Penjualan

- Return On Asset = (Laba Bersih Setelah Pajak $) /$ Total Aset

- Return On Equity = (Laba Bersih Setelah Pajak $) /$ Ekuitas

\section{Analisis SWOT}

Menurut Freddy Rangkuti (2009: 18) Analisis SWOT adalah identifikasi berbagai faktor secara sistematis untuk merumuskan strategi perusahaan. Analisis ini didasarkan pada logika yang dapat memaksimalkan kekuatan (Strengths) dan peluang (Opportunities), namun secara bersamaan dapat meminimalkan kelemahan (Weaknesses) dan ancaman (Threats). Proses pengambilan keputusan strategis selalu berkaitan dengan pengembangan misi, tujuan, strategi, dan kebijakan perusahaan. Dengan demikian perencanaan strategis (strategic planner) harus menganalisis faktor-faktor strategis perusahaan (kekuatan, kelemahan, peluang, dan ancaman) dalam kondisi yang ada saat ini.

\section{METODE PENELITIAN}

Metode penelitian adalah sekumpulan peraturan, kegiatan, dan prosedur yang digunakan oleh pelaku suatu disiplin. Penelitian merupakan suatu penyelidikan yang sistematis untuk meningkatkan sejumlah pengetahuan, juga merupakan suatu usaha yang sistematis dan terorganisasi untuk menyelidiki masalah tertentu yang memerlukan jawaban.

Penelitian ini merupakan penelitian kuantitatif dan deskriptif, yang bertujuan untuk mendeskripsikan, menganalisis, serta menginterpretasikan kondisi-kondisi yang terjadi untuk melihat, mengungkapkan atau menggambarkan secara tepat hal-hal yang sedang dihadapi sekarang.

Dalam melakukan pembahasan, penelitian ini mengukur kinerja keuangan dengan menggunakan rasio keuangan yang terdiri dari Rasio Aktivitas, Rasio Likuiditas, dan Rasio Profitabilitas.

Adapun metode analisis yang digunakan adalah :

1. Menghitung dan menggunakan analisis tren

Rumus:

$$
Y^{1}=\mathrm{a}+\mathrm{bX}
$$

2. Menghitung dan menggunakan analisis rasio keuangan

3. Menghitung dna menggunakan analisis DuPont

Rumus:

$$
R O E=\frac{E A T}{\text { Sales }} X \frac{\text { Sales }}{\text { Total Assets }} X \frac{\text { Total Assets }}{\text { Equity }}
$$

4. Melakukan analisis SWOT 
PT Taisho Pharmaceutical Indonesia Tbk tercatat sebagai emiten di BEI dan menempati sektor farmasi dan memiliki pesaing sebanyak 9. Peringkat market share yang tercatat di Bursa Efek Indonesia pada Sub. Farmasi , yang berada di posisi ke 9 dengan market share sebesar 1,29\%. Ini menandakan bahwa pangsa pasar yang dikuasai sangatlah kecil dibawah 10\% dibandingkan dengan pesaing-pesaing dari perusahaan lain yang ada dalam satu sub sector industry yang sama.

\section{Analisis SWOT}

\section{STRENGTHS}

1. Memiliki produk yang berkualitas

2. Penetapan harga yang kompetitif

3. Inovasi teknologi

\section{WEAKNESSE}

1. Kemampuan mengelola aset rendah

2. Kurangnya aktivitas pemasaran produk

\section{OPPORTUNITIES}

1. Jaringan kerja sama cukup luas

2. Wilayah pemasaran yang belum dimasuki masih banyak dan luas

\section{THREATS}

1. Jenis barang atau produk baru dari pesaing yang bertambah setiap waktu

2. Iklan dan promosi produk dari pesaing

3. Terganggunya pasokan bahan baku

4. Market leader yang memiliki produk dengan harga yang lebih murah

\section{Analisis Laba Rugi}

Penjualan perusahaan pada tahun 2012 sampai dengan 2016 menunjukan tren yang meningkat. Pada tahun 2013 penjualan meningkat 10,04\% pada tahun 2014 16,66\% kemudian pada tahun 2015 turun 3,46\% dan tahun 2016 kembali naik 10\% .Peningkatan penjualan terjadi karena perusahaan mendorong dan mempertahankan penguasaan atas produk OTC (Over The Counter) yaitu "Counterpain" dan "Tempra" di pasar domestik dan memperkuat kinerja sebagai produsen untuk pasar ekspor di Asia Tenggara. Produk etikal juga memberikan kontribusi dalam pertumbuhan penjualan yaitu dengan kekuatan brand Kenacort, Kenalog, dan Mycostatin. Tetapi apabila dibandingkan dengan rata-rata industry sub sektor farmasi PT Taisho Pharmaceutical rada jauh di bawah rata-rata industry sub sektor farmasi. Karena pada market share saja terlihat PT Taisho Pharmaceutical hanya menguasai pasar 1,29\%.

EBIT pada tahun 2012 sampai dengan 2016 menunjukan tren yang meningkat. Peningkatan pada EBIT terjadi karena adanya peningkatan pada penjualan tetapi peningkatan EBIT lebih kecil persentase nya dibandingkan dengan peningkatan penjualan ini menandakan bahwa perusahaan tidak dapat mengelola secara efisen bebanbeban yang dikeluarkan perusahaan. Beban-beban yang dikeluarkan perusahaan lebih besar yang membuat persentase kenaikan EBIT lebih kecil dibandingkan peningkatan penjualan. Seharusnya dengan penjualan yang tiap tahunnya meningkat dapat 
Assets, Assets

Management,

Financial

Performance

\section{Analisis Manajemen Aset}

Current ratio perusahaan, masih diatas 1 yang menandakan perusahaan masih mampu membayar kewajiban jangka pendeknya dengan aset lancarnya. Quick ratio mengalami penurunan. Penurunan trend pada Quick Ratio disebabkan karena adanya peningkatan dari aset lancar dikurangi persediaan dan peningkatan pada hutang lancar. Secara internal sedang mengalami penurunan kinerja tetapi dibandingkan industri berada diatas. Dalam hal ini perusahaan memiliki aset lancar dikurangi persediaan lebih besar dari pada hutang lancar. Kondisi ini menunjukan kemampuan perusahaan untuk membayar hutang lancar melalui aset lancar-persediaan dikatakan baik karena aset lancar dikurangi persediaan yang dimiliki lebih besar dari hutang lancar. Dalam hal likuiditas perusahaan dikatakan likuid. Cash Ratio mengalami penurunan tetapi diatas rata-rata industri. Penurunan tren disebabkan karena adanya peningkatan pada kas dan peningkatan pada hutang lancar. cash ratio pada perusahaan menunjukan bahwa perusahaan dapat memenuhi seluruh kewajiban lancarnya (hutang lancar) dengan menggunakan kas. Hal ini menunjukan bahwa tingkat likuiditas perusahaan dikatakan likuid dan sehat.

Melalui analisis manajemen asset yang ada, perputaran total aset, perputaran aset lancar, perputaran piutang, perputaran persediaan, dan perputaran aset tetap mengalami peningkatan dan berada di atas angka satu. Hal ini menunjukan bahwa secara keseluruhan kemampuan perusahaan menghasilkan penjualan dari total asset dari aset lancar maupun aset tidak lancar yang dimiliki perusahaan yaitu meningkat Ini menunjukan bahwa kemampuan perusahaan yang cukup efisien dalam mengelola total aset yang dimiliki untuk menghasilkan penjualan. Tetapi apabila dibandingkan dengan indutri perputaran keseluruhan aset dikatakan lebih lambat dibandingkan industri sejenisnya. Hal ini menandakan bahwa secara internal perusahaan dikatakan cukup efisien dalam mengelola aktiva untuk meningkatkan penjualan tetapi apabila dibandingkan dengan industri di pasaran perusahaan kurang efisien dalam mengelola aktiva untuk meningkatkan penjualan karena perputarannya di bawah rata-rata industri dan lebih lambat. Dalam hal ini dengan total aset yang dimiliki, manajemen harus lebih efisien lagi dalam mengelolanya guna dapat memaksimalkan penjualan.

\section{Analisis Kemampulabaan}

Analisis kemampulabaan, terlihat rasio Gross Profit Margin (GPM), Operating Profit Margin (OPM), dan Net Profit Margin (NPM), dan Return On Asset (ROA) sejak tahun 2012-2016 menunjukan trend yang menurun. Tetapi berada diatas rata-rata industri. Penurunan ini terjadi karena kenaikan penjualan perusahaan yang tidak sebanding dengan kenaikan yang terjadi pada laba kotor perusahaan. Penurunan ini juga dapat diartikan bahwa perusahaan tidak memaksimalkan laba kotornya karena tidak dapat menekan harga pokok penjualan atau HPP dan beban operasi. Penurunan Gross Profit Margin (GPM), Operating Profit Margin (OPM), dan Net Profit Margin (NPM) menandakan semakin mengalami penurunan keadaan operasi perusahaan, karena hal ini menunjukkan bahwa 
beban pokok penjualan dan beban operasi lebih besar yang dikeluarkan oleh perusahaan. Tetapi apabila dibandingkan dengan industri masih berada diatas rata-rata industri.

Sedangkan Return On Asset (ROA) pada tahun 2012 sampai dengan tahun 2016 menunjukan trend yang menurun dan pada industri, juga menunjukan trend yang menurun. Return On Asset (ROA) berada diatas rata-rata industri. Penurunan Return On Asset (ROA) lebih besar dibandingkan dengan industri. Sekilas di neraca memang laba bersih (EAT) dan total aset terlihat meningkat tetapi persentase kenaikannya justru mengalami penurunan. Penurunan laba bersih disebabkan karena persentase kenaikan beban pokok penjualan dan beban operasi dan beban bunga lebih besar dibandingkan penjualan artinya pengeluaran yang dikeluarkan lebih banyak sehingga mengurangi persentase kenaikan laba bersih, sehingga membuat trend Return On Asset (ROA) menurun. Tetapi apabila secara nominal laba bersih dan aset jauh dibawah rata-rata industry, angka nominalnya sangat kecil dibandingkan pesaingnya. Penurunan persentase laba bersih disebabkan karena perusahaan mencoba melakukan investasi produk baru sehingga persentase kenaikan laba bersih mengalami penurunan.

Hal ini menunjukan bahwa secara keseluruhan kemampuan perusahaan menghasilkan laba bersih dari total aset yang dimiliki perusahaan lebih baik dari industri. Dengan begitu perusahaan dapat dikatakan mampu bersaing dalam hal profitabilitas tetapi kinerjanya sedang mengalami penurunan dari segi pengelolaannya. Selain itu, Return On Asset (ROA) perusahaan yang menurun menunjukan kemampuan perusahaan yang tidak efisien dalam mengelola total aset yang dimiliki untuk menghasilkan laba secara internal.

\section{SIMPULAN DAN SARAN}

\section{SIMPULAN}

Berdasarkan hasil penelitian dan pembahasan diatas, dapat ditarik simpulan sebagai berikut :

1. Bisnis

Bisnis yang dilakukan oleh perusaahaan bergerak pada sub sektor farmasi, pangsa pasar pada sub sektor farmasi berada di posisi ke 9 dari 10 perusahaan pesaing dengan market share sebesar $1,29 \%$. Hal ini menandakan pangsa pasar yang dikuasai sangatlah kecil dibandingkan dengan perusahaan lain yang ada dalam satu sub sektor farmasi.

2. Manajemen Aset

Berdasarkan analisis rasio manajemen aset yang dihasilkan dengan menggunakan CATO, laba usaha terhadap aset lancar, FATO, laba usaha terhadap aset tetap, TATO, laba usaha terhadap total aset, INTO, dan ARTO.

Laba usaha terhadap aset lancar, FATO, laba usaha terhadap aset tetap, laba usaha terhadap total aset yang dihasilkan perusahaan selama lima tahun berada di atas ratarata industri sub sektor tetapi menunjukan tren yang menurun. Hal ini menunjukkan bahwa kemampuan perusahaan dalam memaksimalkan penggunaan aset yang dimiliki baik aset lancar maupun aset tetap untuk menghasilkan keuntungan mengalami kinerja yang menurun walaupun diatas rata-rata industri. Tetapi berdasarkan hasil perhitungan (TATO, CATO, dan ARTO) perusahaan masih berada dibawah rata-rata industi pada sub sektor farmasi. Hal ini menunjukan bahwa perusahaan dalam mengelola dan memanfaatkan aset yang dimiliki kurang efektif. Berdasarkan penelitian, perusahaan memiliki komposisi aset lancar yang lebih
Assets, Assets

Management,

Financial

Performance

151 
Assets, Assets

Management,

Financial

Performance

\section{2}

banyak dari aset tetap. namun perputaran aset lancar perusahaan ini dibawah ratarata dari industri. Bila dilihat dari laporan keuangan, perusahaan memiliki kas yang sangat besar sekali (menumpuk).

3. Kemampulabaan

Berdasarkan analisis rasio kemampulabaan yang dihasilkan, yang dihitung menggunakan GPM, OPM, NPM, ROA selama lima tahun berada di atas rata-rata industri sub sektor farmasi, tetapi dari tahun ketahun mengalami penurunan. Hal ini menunjukkan bahwa kemampuan perusahaan dalam menghasilkan keuntungan baik dari aset, ekuitas atau modal yang digunakan perusahaan berada di atas rata-rata industri sub sektor tetapi mengalami penurunan kinerja. Hal tersebut terjadi karena perusahaan tidak dapat menekan biaya pada harga pokok penjualan, beban operasional secara efisien.

\section{SARAN}

Berdasarkan hasil pembahasan dan simpulan yang ada, maka saran yang dapat diberikan adalah :

1. Perusahaan harus memperluas pasar ekspor / jangkauan pemasaran dan pengiklanan agar produk selalu dikenal oleh konsumen guna meningkatkan pendapatan.

2. Perusahaan harus lebih efektif dalam mengelola asetnya dan meningkatkan pembelian investasi berupa aset tetap guna meningkatkan kapasitas produksi perusahaan semaksimal mungkin.

3. Perusahaan harus mampu menekan biaya operasional sebesar mungkin guna meningkatkan laba usaha.

\section{DAFTAR PUSTAKA}

Boone, Louis E, David L Kurtz. 2007. Pengantar Bisnis Kontemporer, Edisi Ke Sebelas. Jakarta: Salemba Empat.

Brealey, Richard A, Stewart C. Myers and Alan J. Marcus. 2007. Dasar-dasar Manajemen Keuangan Perusahaan. Jilid 1. Jakarta: Erlangga

Brigham, Eugene F. dan Joel F. Houston. 2011. Dasar-dasar Manajemen Keuangan. Edisi 11. Penerjemah Ali Akbar Yulianto. Jakarta: Salemba Empat.

Rangkuti, Freddy. (2009). Strategi Promosi yang Kreatif dan Analisis Kasus. PT. Gramedia Pustaka Utama, Jakarta.

Subramanyam, K. R., \& Wild, J. J. 2013. Analisis Laporan Keuangan. Jakarta: Salemba Empat

Sugiama, A Gima. 2013. Manajemen Aset Pariwisata. Edisi 1. Guardaya Intimarta:Jakarta. 